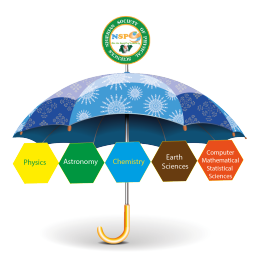

\title{
Optimization of Method and Components of Enzymatic Fuel Cells
}

\author{
S. I. Akinsola*, A. B. Alabi, M. A. Soliu, T. Akomolafe \\ Department of Physics, University of Ilorin, Kwara State, Nigeria.
}

\begin{abstract}
Enzymatic fuel cells produce electrical power by oxidation of renewable energy sources. An enzymatic glucose biofuel cell uses glucose as fuel and enzymes as biocatalyst, to convert biochemical energy into electrical energy. The applications which need low electrical voltages and low currents have much of the interest in developing enzymatic fuel cells. The cell was constructed using three different materials with different electrodes (Bitter leaf and Copper electrodes (BCu), Bitter leaf and Carbon electrodes (BC) and Water leaf and Carbon electrodes (WC)). The short circuit current and open circuit voltage were measured in micro-ampere $(\mu A)$ and milli-volt $(\mathrm{mV})$ respectively at $30 \mathrm{minutes}$ interval over the period of 12 hours (from dawn to dusk). The results which show that fuel cells constructed using bitter leaf with carbon electrode has the highest open circuit voltage, short circuit current and generated power of $162.8 \mathrm{mV}, 1.65 \mu \mathrm{A}$ and $268.62 \mathrm{nW}$ respectively at $720 \mathrm{mins}$ is obtained from the plots generated by the use of Microsoft Excel. The results show that all short circuit currents, voltages and powers generated increases with time and this is as a result of the exposure to solar radiation during the period of taking the measurement.
\end{abstract}

Keywords: Enzymes, Fuel cells, Power generation.

Article History:

Received: 16 September 2019

Received in revised form: 02 November 2019

Accepted for publication: 10 November 2019

Published: 30 December 2019

(c)2019 Journal of the Nigerian Society of Physical Sciences. All rights reserved. Communicated by: W. A. Yahya

\section{Introduction}

The International Energy Agency (IEA) explains renewable energy resources as those derived from natural processes and replenished at a faster rate than they are consumed. The IEA definition of renewable energy includes the following sources: electricity and heat derived from solar, wind, ocean, hydropower, biomass, geothermal resources, and biofuels and hydrogen derived from renewable resources.

A fuel cell is like a battery that generates electricity from an electrochemical reaction. Both batteries and fuel cells convert chemical energy into electrical energy and also, as a by-product

\footnotetext{
${ }^{*}$ Corresponding author tel. no: +2348166602544

Email address: siakinsola711@gmail .com (S. I. Akinsola )
}

of this process, into heat. A fuel cell uses an external supply of chemical energy and can run indefinitely, as long as it is supplied with a source of hydrogen and a source of oxygen (usually air). The source of hydrogen is generally referred to as the fuel and this gives the fuel cell its name, although there is no combustion involved. Oxidation of the hydrogen instead takes place electrochemically in a very efficient way. During oxidation, hydrogen atoms react with oxygen atoms to form water; in the process electrons are released and flow through an external circuit as an electric current [8]. Biological fuel cells convert the chemical energy of carbohydrates, such as sugars and alcohols, directly into electrical energy with the aid of a biological agent, i.e. a single strain or a consortium of microorganisms or isolated microbial enzymes [6]. They use the available substrates from renewable sources and convert them into harmless 
by-products with simultaneous production of electricity [3].

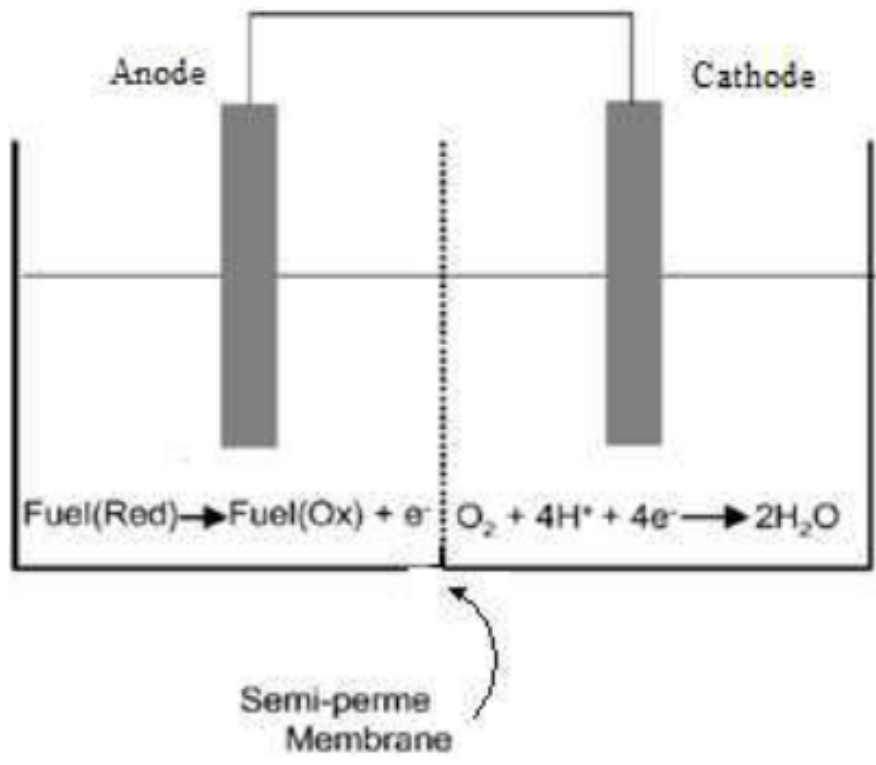

Figure 1: Working principle of a fuel cell [4].

In fuel cells, a substance with reduction properties (fuel) is oxidized at the anode, while the produced electrons are transferred, via an external circuit, to a suitable electron acceptor molecule, or oxidant (such as oxygen) at the cathode [5].

There are two types of biological fuel cells, namely microbial fuel cells (MFCs) and enzymatic fuel cells (EFCs). Microbial biofuel cells employ living cells to catalyze the oxidation of the fuel, whereas enzymatic biofuel cells use enzymes for this purpose. Although they have lower power densities, the current advantage to microbial biofuel cells is that they typically have long lifetimes (up to five years) and are capable of completely oxidizing simple sugars to carbon dioxide [2].

\subsection{Enzymatic Fuel Cell}

Enzymatic fuel cell is a specific type of biofuel cell which uses enzymes as a catalyst to oxidize its fuel, rather than precious metals [4]. Enzymes have a complex structure comprising proteins. The electron-transferring unit of the enzyme, namely the apoenzyme and cofactor, is deeply buried inside its complex structure. Enzymatic fuel cells are compatible with immobilization and wiring, and consequently, can offer high current densities, especially when used in concentration form [6].

\section{Materials and Method}

\subsection{Materials}

The materials and equipment used in the development of the enzymatic biofuel cell are:

Glucose oxidase (EC 1.1.3.4, GOx) from Waterleaf (Talinum triangulare) and Bitter leaf (Vernonia amygdalina), Dglucose, digital multimeter, micro-ammeter, distilled water, agar, salt $(\mathrm{NaCl})$, copper, carbon, Potassium Dihydrogen Phosphate $\left(\mathrm{KH}_{2} \mathrm{PO}_{4}\right)$, Disodium Hydrogen Phosphate $\left(\mathrm{Na}_{2} \mathrm{HPO}_{4}\right)$, beaker, stirrer, the cooking gas, Soldering iron, $\mathrm{PVC}$ pipe, transparent plastic containers, jumper wire, paper tape, glue.

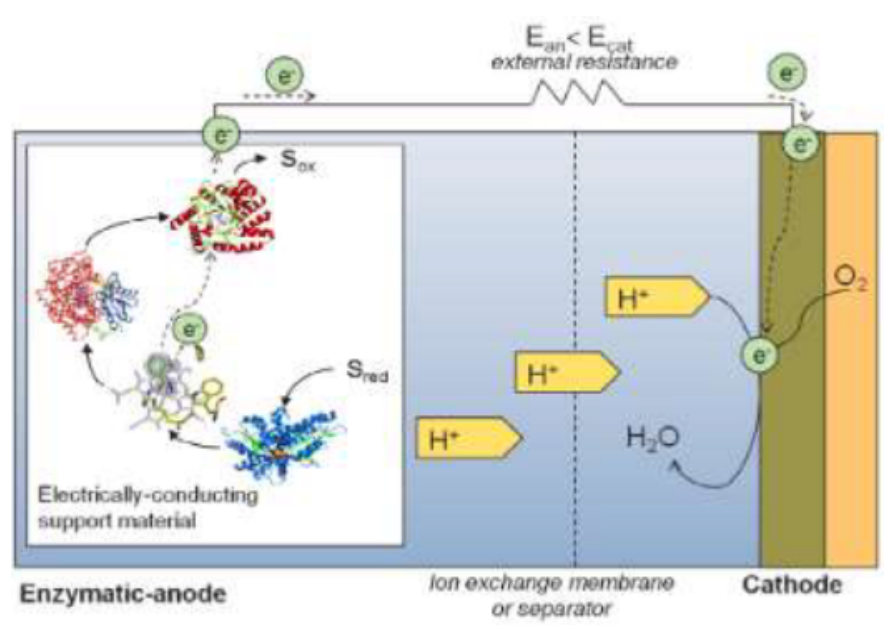

Figure 2: Schematic diagram of an enzymatic fuel cell [1].

\subsection{Methodology}

\section{Preparation of Buffer Solution}

The solution of phosphate buffer $\mathrm{pH} 7.0$ was prepared by dissolving $0.50 \mathrm{~g}$ of anhydrous disodium hydrogen phosphate $\left(\mathrm{Na}_{2} \mathrm{HPO}_{4}\right)$, and $0.35 \mathrm{~g}$ of potassium dihydrogen phosphate $\left(\mathrm{KH}_{2} \mathrm{PO}_{4}\right)$ in sufficient water to produce $1000 \mathrm{ml}$.

\section{Construction of the Separator (Ion Electrolyte Membrane).}

In constructing the polymer, 9 grammes of agar and 11.6 grammes of sodium chloride was measured and mixed with $10 \mathrm{ml}$ of distilled water inside a beaker with the help of a stirrer. It was placed on the Bunsen burner to heat for about 5 minutes and then allowed to cool. It was poured inside the PVC pipe blocked at one end (the PVC pipe was blocked at one to avoid leakage of the solution), then leave it for some minutes to totally cool to give a solidified form which stayed fixed inside the PVC pipe and serves as the separator.

\section{Construction of the cell}

An enzymatic biofuel cell consists of an anode and a cathode chambers. The two chambers were constructed using two transparent four-sided plastic containers. A hole was drilled at one-side of each container by the use of a soldering iron. The two chambers were separated by an ion exchange membrane prepared from a solution of agar and salt $(\mathrm{NaCl})$ inside a PVC pipe. The PVC pipe containing the polymer was inserted in the drilled holes of the two containers using glue to make it tight and to prevent leakage and air. The anode chamber was then filled with the D-glucose which serve as the fuel, glucose oxidase which serves as the enzyme, catalase which is the oxidant, phosphate buffer $\mathrm{pH} 7.0$ which helps in maintaining the $\mathrm{pH}$, temperature and the concentration, and an electrode (carbon) while the cathode chamber was filled with distilled water and an electrode. The ion exchange membrane serves as a separator of the two chambers and also facilitates the transfer of protons 
and electrons from the anode to the cathode. A tiny hole was drilled in the covers of the two containers for the passage of a probe each. The electrode (carbon) was immersed deeply inside each of the container with the use of one end of the probes leaving the other end as the positive and negative terminal of the cell. Then the probes were sealed to the covers of the container to make it fixed and to prevent air.

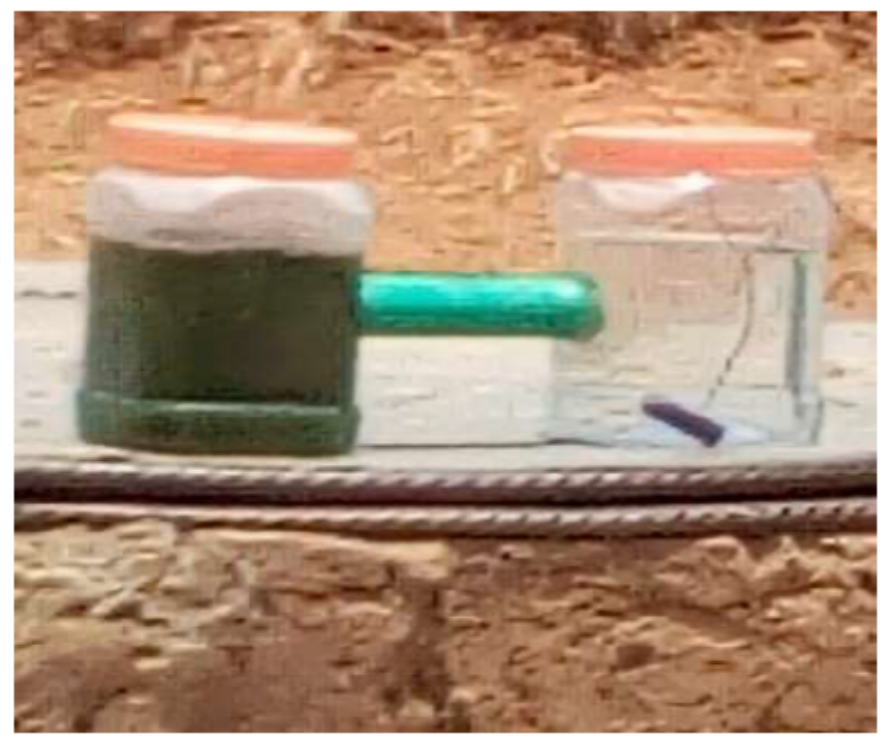

Figure 3: Construction Image.

\section{Measurements}

The open circuit voltage and the current of the enzymatic fuel cell were measured in millivolts $(m V)$ and micro ammeter $(\mu A)$ respectively at 30 minutes interval over a period of 12 hours (From dawn to dusk). Micro ammeter was used because the current generated was very small.

\section{Results and Discussion}

The short circuit current and open circuit voltage were measured in micro-ampere $(\mu A)$ and millivolt $(m V)$ respectively at 30 minutes interval over the period of 12 hours. The measurements were made for the three cells constructed, i.e. fuel cell using bitter leaf and Copper electrodes $(\mathrm{BCu})$, using Bitter leaf and Carbon electrodes (BC) and using Water leaf and Carbon electrodes (WC). Figures 4, 5, and 6 show the variation of the current, voltage and power measured with time from the three cells respectively.

From figures 4, 5 and 6 above, it was observed that the current generated by the fuel cells ranges from $0.72-1.32 \mu \mathrm{A}, 0.78-$ $1.65 \mu \mathrm{A}$ and $0.60-1.24 \mu \mathrm{A}$ for fuel cell constructed using Bitter leaf with Copper electrodes, Bitter leaf with Carbon electrodes and Water leaf with Carbon electrodes respectively, while the voltage generated by the cells ranges from $34.2-116.8 \mathrm{mV}, 51.3-$ $162.8 \mathrm{mV}$ and $11.7-90.81 \mathrm{mV}$ for fuel cell constructed using

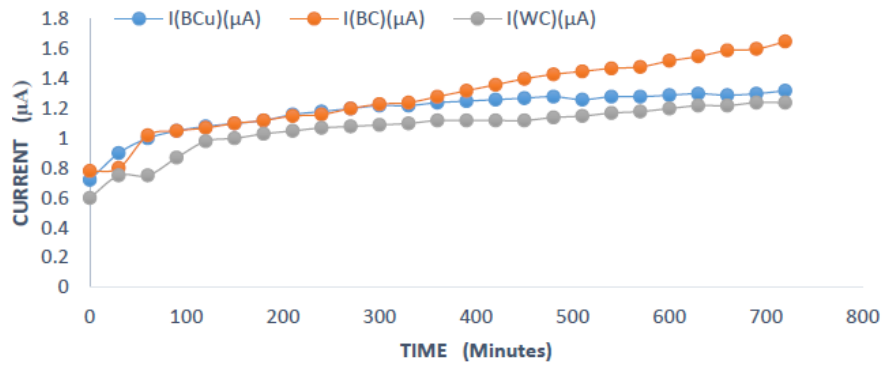

Figure 4: Current measurements for the three fuel cells.

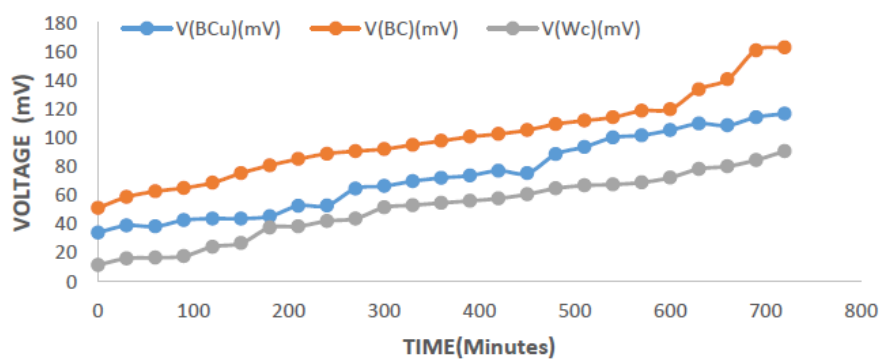

Figure 5: Voltage measurements in the three fuel cells.

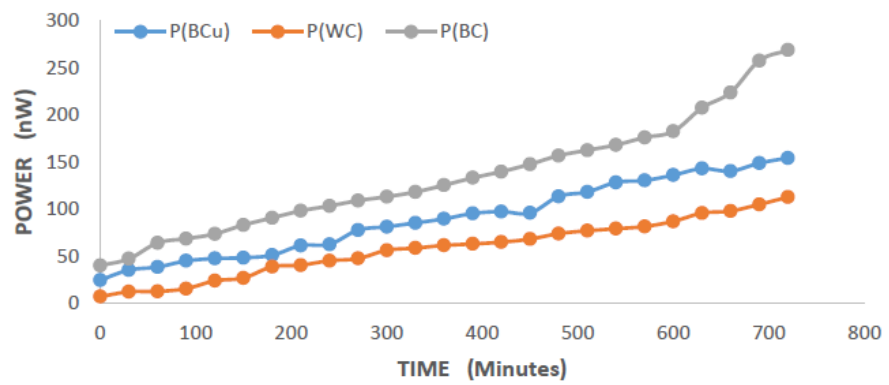

Figure 6: Power measurements for the three fuel cells.

Bitter leaf and Copper electrodes, Bitter leaf with Carbon electrodes and Water leaf with Carbon electrodes respectively. The fuel cell constructed using Bitter leaf with Carbon electrodes generated the highest open circuit current and voltage, followed by that constructed using Bitter leaf with Copper electrodes, while that constructed using Water leaf with Carbon electrodes generated the least open circuit current and voltage. The low spikes in the graph shows the moment with minimal solar irradiation or cloudy weather.

The current and voltage generated by the fuel cells increases steadily from the initial point (at time 0 second). As shown in figure 4, the current gain of the fuel cells per time is not as much as the voltage gain per time of the cells shown in figure 5 as the voltage gain of the cells shows a steeper slope than the current gain. This shows that the potential difference between the electrodes and the rate of transfer of electron through separator is lowest in the fuel cell constructed using Water leaf with Carbon electrodes but highest in the fuel cell constructed using Bitter leaf with Carbon electrodes. This might owe to the fact that electron transport mechanism which takes place with the used electrodes favour this performance. Generated electrons during oxidation reaction should reach the anodic electrode to 
enter into the power circuit. The higher current generated by the bitter leaf cell as compared with the other cell could be as a result of the concentration of electrons in the used bitter leaf which will in turn has high electrons content reaching the electrode and hence generating highest electric current, compared to cells with other type of leaf. The carbon electrode used could also be responsible for the increased in electron mobility than the other type of electrode used. Carbon has graphite as one of its allotrope, which could have a work function lower than copper and hence eject electrons from it faster than copper. The cell constructed using Bitter leaf with Copper lies between the two. The power generated by the fuel cells follows a similar trend with the current and voltage generated.

Theoretically, the results obtained from this experiment could be modeled using the equation used for treating RC circuit, which is suggesting the fuel cells working like a capacitor.

$$
V_{c}(t)=V_{s}\left(1-e^{-t / R C}\right),
$$

the quantity $\mathrm{RC}$ is the time constant of the system. Equation 1 describes when the capacitor is charging while equation 2 is for when it is discharging.

$$
V_{c}(t)=V_{s} e^{-t / R C},
$$

although this is subject to further studies.

\section{Conclusion}

In this work, three types of enzymatic fuel cells have been constructed and the open circuit current and voltage generated by the fuel cells were measured in the interval of 30 minutes over the period of 12 hours. The results show that fuel cells constructed using bitter leaf with carbon electrode has the highest maximum open circuit voltage of $162.8 \mathrm{mV}$ and the highest maximum short circuit current of $1.65 \mu \mathrm{A}$ and highest maximum power of $268.62 n \mathrm{~W}$ at time 720 mins. The construction with the lowest maximum open circuit voltage of $90.8 \mathrm{mV}$, the lowest maximum short circuit current of $1.24 \mu \mathrm{A}$ and the lowest maximum power of $112.592 \mathrm{nW}$ at time $720 \mathrm{mins}$ is waterleaf with carbon.

\section{Acknowledgments}

We thank the referees for the positive enlightening comments and suggestions, which have greatly helped us in making improvements to this paper.

\section{References}

[1] D. X. Benetton, S. Srikanth, Y. Satyawali, K. Vanbroekhoven \& D. Pant, "Enzymatic Electrosynthesis: An Overview on the Progress in Enzyme Electrodes for the Production of electricity, Fuels and Chemicals", Journal of Microbial \& Biochemical Technology 007 (2013) doi: 10.4172/1948-5948.S6-007.

[2] S. D. Minteer, B. Y. Liaw \& M. J. Cooney, "Enzyme-Based Biofuel Cells", Current Opinion in Biotechnology 18 (2007) 228.

[3] Y. Mohan, K. S. Manoj Muthu \& D. Das, "Electricity Generation Using Microbial Fuel Cells", International Journal of Hydrogen Energy 33 (2007) 423.

[4] M. Patil, P. Pawar, M. A. K. Kerawalla \& P. Goswami, "Enzymatic Biofuel Cells - A Progress Review", Journal of Chemical, Biological and Physical Sciences 6 (2016) 39.

[5] D. Sell, "Bioelectrochemical Fuel Cells", Biotechnology 10 (2001).

[6] A. K. Shukla, P. Suresh, S. Berchmans \& A. Rajendran, "Biological Fuel Cells and Their Applications", Current Science 87 (2004) 455.

[7] Y. Song, V. Penmasta \& C. Wang, "Recent Development of Miniatured Enzymatic Biofuel Cells", Biofuel's Engineering Process Technology (2011).

[8] http://www.fuelcelltoday.com/analysis/patents/2011/2011-patent-review (assessed June, 2019) 